\title{
PENINGKATAN KEMAMPUAN BERBAHASA INDONESIA MELALUI METODE DRAMA PADA SISWA KELAS VIIC SMP DHARMA PRAJA
}

\author{
I Nyoman Juniardianta \\ Universitas Warmadewa \\ Juni.ardianta@yahoo.co.id
}

\begin{abstract}
Abstrak
Kemampuan berbahasa Indonesia bukan saja diperlukan di depan kelas, di muka guru atau dihadapan teman-teman. Kemampuan ini juga digunakan dalam seluruh kegiatan manusia sehari-hari, terutama dalam kondisi formal. Siswa harus bisa menggunakan bahasa Indonesia yang relevan dari sejak dini. Kemampuan berbahasa Indonesia siswa kelas VIIC pada awal penilaian (pretest) $86 \%$ masih dibawah kriteria ketuntasan minimal (KKM). Oleh sebab itu agar siswa kelas VIIC dapat meningkatkan kemampuan berbahasa Indonesia

metode yang digunakan dalam penelitian ini adalah metode drama yang bersifat formal. Dari metode drama formal kreativitas siswa dalam memilih diksi dan tata bahasa dengan bahasa Indonesia yang relevan akan semakin meningkat. Peningkatan yang diperoleh siswa kelas VIIC dalam meningkatkan kemampuan berbahasa Indonesia yang relevan melalui metode drama yaitu sebesar $93 \%$. Hal tersebut menunjukkan bahwa metode drama formal sangat efektif dalam meningkatkan berbahasa Indonesia yang relevan pada siswa kelas VIIC SMP Dharma Praja.
\end{abstract}

Kata kunci: kemampuan berbahasa Indonesia dan metode drama

\begin{abstract}
Indonesian language skills are not only necessary in front of the class, upfront teacher or in front of friends. This capability is also used in all human activites daily, especially in conditions of formal. Student should be able to use the relevant Indonesian from early. Indonesian language skills VIIC grade students at the beginning of the assessment (Pretest) $86 \%$ is still below the minimum completeness criteria. Therefore in order grades VIIC can improve the ability to speak Indonesian the method used in this study is a drama that is formal. Of formal methods of drama students' creativity in choosing diction and grammar with relevant Indonesian will increase. Improvement gained VIIC grade students in improving the relevant Indonesian language skills through drama methodes, namely by 93\%. It shows that the method of formal drama is very effective in improving the relevant Indonesian language in class VIIC SMP Dharma Praja.
\end{abstract}

\section{Keywords: the ability to speak Indonesian and methods of drama}

\section{PENDAHULUAN}

Bahasa adalah alat komunikasi antarmanusia. Alat komunikasi bentuknya beraneka ragam ada alat komunikasi berupa bunyi vokal, ada pula alat komunikasi berupa bunyi tetapi tidak vokal (misalnya suara pluit, kentongan, sirena, dan lainlain), dan ada pula alat komunikasi yang tidak berupa bunyi (seperti: gerakan tangan, kepala, lampu pengatur lalulintas, atau tanda-tanda lain). (Arnawa: 2008: 20).
Bahasa juga merupakan seperangkat simbol bunyi yang dihasilkan organ bicara manusia yang ditata dalam sistem suatu bahasa sehingga menjadi kata dan atau kalimat pada hakikatnya merupakan simbol atau lambang atas sesuatu yang dilambangkannya. Hubungan simbol (lambang) dengan yang disimbolkan (dilambangkan) bersifat arbriter. Bahasa sebagai sistem simbol dapat digunakan untuk menyimbolkan sesuatu yang ada 
diluar bahasa (ekstralinguistik). Bahasa dapat digunakan untuk melambangkan peristiwa, sesuatu benda, orang, tindakan, keadaan, dan lain-lain yang bukan bahasa. Kurangnya pemahaman berbahasa Indonesia disebabkan oleh beberapa faktor. Faktor yang pertama adalah rendahnya kepedulian terhadap pengetahuan berbahasa Indonesia, faktor yang kedua adalah guru bahasa Indonesia kurang memberikan pemahaman berbahasa Indonesia. Faktor yang ketiga adalah monotonnya pelajaran bahasa Indonesia yang diberikan oleh para guru bahasa Indonesia di kelas sehingga para siswa menjadi bosan dan tidak menyukai pelajaran ba Konsep

Tema drama dalam penelitian ini yaitu tentang drama formal. Melalui drama formal akan membuat siswa berbahasa Indonesia dengan relevan. Model pembelajaran drama dalam meningkatkan kemampuan berbahasa Indonesia adalah suatu model dalam pembelajaran melalui bermain peran secara formal agar siswa bisa memiliki kreativitas dalam menentukan diksi dan tata bahasa sesuai kaidah bahasa Indonesia yang relevan. Dengan demikian siswa dapat menambah wawasan berbahasa Indonesia sesuai dengan kebutuhannya dalam berbahasa Indonesia. Ada beberapa konsep yang dijadikan sebagai kerangka acuan bagi peneliti yang dijelaskan dibawah ini.

\section{KONSEP DAN KERANGKA TEORI}

\section{Konsep}

\section{Kontribusi Konsep}

Menurut Aliseptiansyah (2014:7-9) konsep berbahasa Indonesia adalah Bahasa Indonesia yang digunakan sesuai dengan situasi pembicaraan (yakni, sesuai dengan lawan bicara, tempat pembicaraan, dan ragam pembicaraan) dan sesuai dengan kaidah yang berlaku dalam Bahasa Indonesia (seperti: sesuai dengan kaidah ejaan, pungtuasi, istilah, dan tata bahasa).

Adapun berbahasa Indonesia yang sesuai golongan adalah berbahasa Indonesia yang sesuai dengan kaidah yang berlaku dalam bahasa Indonesia. Dengan kata lain, pemakaian bahasa yang mengikuti kaidah yang dibakukan atau yang dianggap baku itulah yang merupakan bahasa yang benar atau betul.

Jadi, terkadang kita menggunakan bahasa yang baik, artinya tepat, tetapi tidak termasuk bahasa yang benar. Sebaliknya, terkadang pula mungkin kita menggunakan bahasa yang benar yang penerapannya tidak baik karena situasi mensyaratkan ragam bahasa yang baku.

Konsepsi bahasa Indonesia tersebut menunjukkan bahwa sistem lambang bunyi ujaran dan lambang tulisan digunakan untuk berkomunikasi dalam masyarakat dan lingkungan akademik. berbahasa Indonesia yang baik dikembangkan oleh pemakainya berdasarkan kaidah-kaidahnya yang tertata suatu sistem. Kaidah bahasa dalam sistem tersebut mencakup beberapa hal berikut ini diantaranya: 
1) Sistem lambang yang bermakna dapat dipahami dengan baik oleh masyarakatnya.

2) Berdasarkan kesepakatan masyarakat pemakainya, sistem bahasa Indonesia itu bersifat konvensional.

3) Lambang sebagai huruf (fonemis) bersifat manasuka atau kesepakatan pemakai (arbriter).

4) Sistem lambang yang terbatas itu (A-Z: 26 huruf) mampu menghasilkan kata, bentukan kata, frasa, kalusa, dan kalimat yang tidak terbatas dan sangat produktif.

5) Sistem lambang bahasa itu dibentuk berdasarkan aturanyang bersifat universal sehingga dapat sistem lambang bahasa lain. Unsur dalam sistem lambang tersebut menunjukkan bahwa bahasa itu bersifat unik, khas, dan dapat dipahami masyarakat.

Menurut Pilami (2015) konsep berbahasa Indonesia adalah suatu sistem tanda bunyi yang secara sukarela dipergunakan oleh anggota kelompok sosial untuk bekerja sama, berkomunikasi, dan mengidentifikasi diri. Bahasa yang berkembang berdasarkan suatu sistem, yaitu seperangkat aturan yang dipatuhi oleh pemakainya. sistem tersebut mencakup unsur-unsur berikut.
Sistem lambang yang bermakna dan dapat dipahami oleh masyarakat pemakainya berdasarkan kesepakatan. lambang-lambang tersebut bersifat arbriter (kesepakatan) digunakan secara berulang dan tetap. Sistem lambang tersebut bersifat terbatas, tetapi produktif. Artinya, dengan sistem yang sederhana dan jumlah aturan yang terbatas dapat menghasilkan jumlah kata, frasa, klausa, kalimat, paragraph, dan wacana yang tidak terbatas jumlahnya.

Sistem lambang bersifat unik, khas, dan tidak sama dengan lambang lain sistemlambang dibangun berdasarkan kaidah yang bersifat universal. Pada dasarnya, bahasa memiliki fungsi-fungsi tertentu yang digunakan berdasarkan kebutuhan seseorang, yakni sebagai alay untuk mengekspresikan diri, sebagai alat untuk berkomunikasi, sebagai alat untuk mengadakan integrasi dan beradaptasi sosial dalam lingkungan atau situasi tertentu,dan sebagai alat untuk melakukan kontrol sosial.

Menurut Martaulina (2015:33) konsep berbahasa Indonesia menunjukkan bahawa sistem lambang bunyi ujaran dan lambang tulisan digunakan untuk berkomunikasi dalam masyarakat dan lingkungan akademik. Bahasa Indonesia yang baik dikembangkan oleh pemakainya berdasarkan kaidah-kaidahnya yang tertata dalam suatu sistem. kaidah bahasa Indonesia dalam sistem tersebut mencakup beberapa hal berikut.

1) Sistem lambang yang bermakna dapat 
dipahami dengan baik oleh masyarakatnya.

2) Berdasarkan kesepakatan masyarakat pemakainya, sistem bahasa itu bersifat konfensional.

3) Lambang sebagai huruf (fonemis) bersifat manasuka atau kesepakatan

Dari ketiga definisi diatas dapat disimpulkan bahwa konsep berbahasa Indonesia adalah kemampuan memilih ragam bahasa yang tepat. Sesuai dengan peristiwa atau keadaan yang dihadapi. serta konsep bahasa Indonesia yang benar dapat dilihat dari kemampuan menggunakan bahasa Indonesia yang sesuai dengan kaidah (diksi dan tata bahasa).

\section{Fungsi Bahasa Indonesia}

Menurut Badrih (2016) Fungsi bahasa Indonesia sebagai Bahasa Nasional sehubungan dengan kedudukannya sebagai bahasa nasional, bahasa Indonesia memiliki empat fungsi. Keempat fungsi tersebut ialah sebagai berikut:

1) Lambang identitas nasional

2) Lambang kebanggaan nasional

3) Alat pemersatu berbagai masyarakat yangmempunyai latar belakang sosial budaya dan bahasa yang berbeda-beda, dan

4) Alat perhubungan antar budaya dan daerah

Fungsi bahasa Indonesia sebagai bahasa negara, berkaitan dengan statusnya sebagai bahasa negara, bahasa Indonesia berfungsi sebagai berikut:

1) Bahasa resmi negara

2) Bahasa pengantar resmi di lembagalembaga pendidikan

3) Bahasa resmi dalam perhubungan tingkat nasional untuk kepentingan perencanaan dan pelaksanaan pembangunan serta pemerintahan

4) Bahasa resmi di dalam penegmbangan kebudayaan dan pemanfaatan ilmu pengetahuan serta teknologi bahasa Indonesia baku. Bahasa Indonesia yang baku adalah bahasa Indonesia yang digunakan orang-orang terdidik dan dipakai sebagai tolak bandingan penggunaan bahasa yang dianggap benar.

Pemakaian bahasa Indonesia dalam dunia pendidikan diantaranya;

1) Bahasa Indonesia digunakan sebagai bahasa pengantar dalam proses pembelajaran sejak TK sampai perguruan tinggi.

2) Bahasa Indonesia digunakan untuk penulisan buku-buku pelajaran (buku teks) penerjemahan buku-buku refrensi dalam berbagai bidang ilmu, penyajian materi disemua lembaga pendidikan untuk masyarakat umum

3) Bahasa Indonesia digunakan untuk menyampaikan laporan hasil belajar peserta didik baik dalam buku laporan pendidikan (raport) maupun dalam bentuk laporan hasil belajar yang baik. 
4) Bahasa Indonesia digunakan untuk pengembangan bahan ajar, strategi pembelajaran, evaluasi pembelajaran, pengelolaan sumber belajar, pembuatan dan penggunaan media pembelajaran

Bahasa Indonesia sebagai bahasa ilmu pengetahuan teknologi antara lain untuk;

1) Melaksanakan penelitian dalam berbagai bidang ilmu

2) Menerjemahkan berbagai buku, artikel, laporan penelitian, dan karya-karya ilmiah yang laindari bahasa-bahasa asing ke dalam bahasa Indonesia

3) Menulis berbagai buku refrensi dalam berbagai bidang ilmu

4) Bahasa pengantar dalam berbagai kegiatan seminar, diskusi, dialog, loka karya dalam berbagai ilmu pengetahuan

5) Bahasa komunikasi antara para ahli dalam bidang ilmu sejenis maupun lintas bidang IPTEK

Menurut Sugono (2009:1-2) kedudukan dan fungsi bahasa Indonesia berdasarkan pengelompokkan bahasa-bahasa dalam rumpun austronesia, bahasa Indonesia termasuk kelompok melayu polinesia barat. dalam kelompok ini terdapat 175 bahasa (satu diantaranya bahasa Indonesia). Sejak diikrarkan sumpah pemuda dalam kongres pemuda 28 oktober 1928, bahasa Indonesia menjadi bahasa nasional. Kedudukan bahasa Indonesia sebagai bahasa nasional dimungkinkan oleh oleh kenyataan bahwa bahasa melayu yang mendasari bahasa Indonesia itu telah dipakai lingua franca selama berabad-abad sebelum diseluruh kawasan nusantara.

Menurut Fahrurrozi dan Wicaksono, (2016:59) Fungsi Bahasa Indonesia baku mempunyai empat fungsi yaitu pemersatu, (2) penanda kepribadian, (3) penambah wibawa, (4) kerangka acuan. Pertama, bahasa Indonesia baku berfungsi pemersatu. Bahasa Indonesia baku memepersatukan atau menghubungkan penutur berbagai dialek bahasa itu. Bahasa Indonesia baku memepersatukan mereka menjadi satu masyarakat bahasa Indonesia baku. Bahasa Indonesia baku mengikat kebhinekaan rumpun dan bahasa yang ada di Indonesia dengan mengatasi batas-batas kedaerahaan. Bahasa Indonesia baku merupakan wahana atau alat dan pengungkap kebudayaan nasional yang utama. Fungsi pemersatu ini ditingkatkan melalui usaha pemberlakukannya sebagai salah satu syarat atau ciri manusia Indonesia modern.

Kedua bahasa Indonesia baku berfungsi sebagai penanda kepribadian. Bahasa Indonesia baku merupakan ciri khas yang membedakannya dengan bahasa-bahasa lainnya. Bahasa Indonesia baku memperkuat perasaan kepribadian nasional Indonesia, dengan bahasa Indonesia baku kita menyatakan identitas kita. Bahasa Indonesia baku dianggap sudah berbeda dengan bahasa melayu riau yang menjadi induknya.

Ketiga, bahasa Indonesia baku berfungsi penambah wibawa bangsa. Kepemilikan bahasa Indonesia baku akan membawa serta 
wibawa. Fungsi pembawa wibawa berkaitandengan usaha mencapai kesederajatan dengan peradaban lainyang dikagumi melalui pemerolehan bahasa baku. Disamping itu, pemakai bahasa yang mahir berbahasa Indonesia baku dengan baik dan benar memperoleh wibawa itu juga terlaksana jika bahasa Indonesia baku dapat dipautkan dengan hasil teknologi baru dan unsur kebudayaan baru. Warga masyarakat secara psikologis akan mengidentifikasikan bahasa Indonesiabaku dengan masyarakat dan kebudayaan moderndan maju sebagai pengganti pranata, lembaga bangunan indah, jalan raya yang besar. Gengsi juga melekat pada bahasa Indonesia karena ia dipergunakan oleh masyarakat yang berpengaruh yang menambah wibawa pada setiap orang yang mampu menggunakan bahasa Indonesia yang baku.

Dari ketiga definisi tentang fungsi bahasa Indonesia diatas dapat disimpulkan bahwa sebagai alat komunikasi secara umum baik secara lisan maupun tulisan untuk mengekspresikan diri serta sebagai alat berintegrasi, beradaptasi sosial dan sebagai alat kontrol sosial. Penilaian

\section{Kemampuan Berbahasa Indonesia}

Untuk mengetahui keberhasilan suatu kegiatan tentu memerlukan penilaian. Ada kecendrungan guru bahasa memberikan penilaian berdasarkan kesan umum, baik dalam kemampuan berbahasa secara tertulis maupun secara lisan. Siswa tidak mengetahui di mana kelemahannya dan apa yang sudah dikuasainya dan apa yang perlu ditingkatkannya, karena kemampuan berbahasa Indonesia yang baik dan benar didukung oleh beberapa aspek.

Khusus untuk penilaian berbahasa Indonesia, disamping mencatat kekurangankekurangan siswa, penulis juga mencatat kemajuan yang sudah mereka capai. Hal ini sangat penting karena hasil penilaian itu harus disampaikan secara lisan kepada mereka. Untuk memotivasi mereka dalam berbahasa Indonesia, penulis hendaknya menunjukkan hasil yang sudah dicapai. Informasi yang dicatat dalam penilaian sungguh merupakan umpan balik yang tak ternilai bagi mereka. Berikut ini aspekaspek yang dinilai dalam meningkatkan kemampuan berbahasa Indonesia antara lain;

1. Diksi dan Ungkapan (ketepatan dan kesesuaiannya)

Diksi adalah memilih kata yang tepat dan selaras untuk menyatakan atau mengungkapkan gagasan sehingga memperoleh efek tertentu. Pilihan kata merupakan satu unsur sangat penting, baik dalam dunia karang-mengarang maupun dalam dunia tutur setiap hari.

Ada beberapa pengertian diksi di antaranya adalah membuat pembaca atau pendengar mengerti secara benar dan tidak salah paham terhadap apa yang disampaikan oleh pembicara atau penulis, untuk mencapai target komunikasi yang efektif, melambangkan gagasan yang 
diekspresikan secara verbal, membentuk gaya ekspresi gagasan yang tepat (sangat resmi, resmi, tidak resmi) sehingga menyenangkan pendengar atau pembaca.

Diksi, dalam arti pertama merujuk pada pemilihan kata dan gaya ekspresi oleh penulis atau pembicara. Arti kedua lebih umum digambarkan dengan kata-kata seni berbicara jelas sehingga setiap kata dapat didengar dan dipahami hingga kompleksitas dan ekstrimitas terjauhnya. Pengertian pilihan kata atau diksi jauh lebih luas dari apa yang dipantulkanoleh hubungan katakata itu. Istilah ini bukan saja dipergunakan untuk menyatakan kata-kata mana yang dipakai untuk mengungkapkan suatu ide atau gagasan, tetapi meliputi juga fraselogi, gaya bahasa,dan ungkapan.

Seorang pengarang ketika menentukan suatu kata dalam menulis, ternyata tidak asal dalam memilih kata, namun demikian kata yang akan dipilih itu akan diikuti dengan berbagai hal yang melingkupinya. Hal tersebut menyangkut dimana, kapan, dan tujuannya apa menggunakan kata tersebut. Gagasan atau ide yang dituangkan, baik itu dalam bentuk tulisan maupun dalam bentuk lisan memerlukan kosa kata yang luas, akan tetapi tidak asal memasukan kosa kata yang dimiliki itu dalam tulisan. Azka (2015).

\section{Tata Bahasa}

Tata bahasa adalah cabang ilmu pengetahuan yang mempelajari kaidahkaidah yang mengatur penggunaan bahasa.
Tata bahasa juga merupakan suatu himpunan dari patokan-patokan dalam struktur bahasa. Struktur bahasa itu meliputi tata bunyi, tata bentuk, tata kata, tata kalimat dan tata makna. dengan kata lain, tata bahasa meliputi bidang-bidang fonologi, morfologi, dan sintaksis.

Secara umum tata bahasa bersifat normatif (umum) yaitu tata bahasa tersebut disusun berdasarkan gejala-gejala bahasa yang umum dipakai dalam suatu masyarakat. Suatu tata bahasa normatif memberikan uraian atas struktur umum dari suatu bahasa. Tetapi mengingat bahwa bahasa selalu berkembang setiap saat, maka selalu ada perubahan yang terjadi atas struktur bahasa, oleh karena itu tata bahasa normatif harus tetap mengikuti perkembangan itu. dengan kata lain tata bahasa normatif harus tetap bersifat deskriptif.

Pada bahasa yang sudah tidak dipakai lagi dalam komunikasi sehari-hari tata bahasa normatif dari bahasa-bahasa tersebut selalu bersifat preskiptif yaitu menentukan atau mengatur kaidah-kaidah itu harus diikuti secermat-cermatnya, dan tidak boleh diubah lagi. Berdasarkan cara penyusunannya, tata bahasa dapat dibedakan menjadi 2 yaitu:

1) Tata bahasa deskriptif (sinkronis) adalah tata bahasa yang disusun berdasarkan pencatatan (deskripsi) yang nyata atas struktur suatu bahasa. Tata bahasa ini biasanya meliputi suatu lingkungan masa yang tertentu. 
2) Tata bahasa historis-komparatif (diakronis) adalah tata bahasa yang membicarakan perkembangan struktur bahasa dari satu jaman ke jaman lain, serta mengadakan perbandingan antara struktur-struktur bahasa dari bermacammacam jaman itu atau memperbandingkannya dengan bahasabahasa lainnya (komparatif).

Dalam bahasa Indonesia terdapat 4 bidang tata bahasa modern dalam bahasa Indonesia yaitu meliputi bidang-bidang sebagai berikut:

1) Fonologi adalah bagian dari tata bahasa atau bidang ilmu yang menganalisis bunyi bahasa secara umum. Fonologi merupakan ilmu tentang perbendaharaan fonem sebuah bahasa serta distribusinya.

2) Fonemik adalah bagian fonologi yang mempelajari bunyi ujaran menurut fungsinya sebagai pembeda arti.

3) Morfologi adalah bidang linguistik atau tata bahasa yang mengkaji tentang pembentukan kata atau morfem-morfem dalam suatu bahasa. Morfologi disebut juga sebagai tata bentuk. Morfem merupakan satuan ujaran yang memiliki makna gramatikal atau leksikal yang turut serta pada pembentukan kata atau yang menjadi bagian dari kata. Markijar (2016).

\section{Konsep Drama}

Menurut Fauzi (2011:81) drama adalah cerita yang menggambarkan kehidupan dan watak setiap tokohnya, melalui tingkah laku dan dialog atau percakapan yang di pentaskan. Pemain laki-laki dalam drama disebut aktor. Sedangkan pemain perempuan dalam drama disebut aktris. Dalam naskah drama yang akan diperankan ini tergambarkan kehidupan dan watak tokoh melalui tingkah laku serta dialogdialog yang digunakan. Dalam bermain peran (drama) harus memperhatikan hal-hal berikut ini yaitu; (1) vokal, (2) tekanan suara, (3) emosi, (4) gestur, dan (5) konsentrasi terlebih dahulu.

Latihan vokal dapat dilakukan melalui pengucapan a,i,e,o,e

Latihan tekanan suara dilakukan dengan mengucapkan kalimat-kalimat yang mendapatkan tekanan pada kata-kata tertentu.

Latihan emosi dilakukan dengan melatih kepekaan hati atau perasaan hingga menjadi mudah untuk diajak berekspresi baik untuk marah, menangis, tertawa, membentak, dan sebagainya.

Latihan gesture untuk melatih gerak tubuh untuk mendukung ekspresi dialog, misalnya; menunjuk tangan, mengangkat kedua telapak tangan sebagai ekspresi kepasrahan, berjalan mondar-mandir sebagai ekspresi kepanikan dan sebagainya.

Latihan konsentrasi dilakukan dengan pemusatan pikiran agar pikiran dan perasaan jernih (Fairul Zabadi dan Sutejo dkk, 2014:66-67).

Menurut Suratmi (2014) drama adalah bentuk karya sastra yang menggambarkan kehidupan dengan menyampaikan 
perselisihan atau permasalahan dan emosi atau perasaan melalui perbuatan dan dialog. Drama dianggap sebagai sebuah karya satra yang sangat berperan penting di dalam kehidupan manusia atau peniruan gerak yang memanfaatkan unsur-unsur aktivitas nyata. Dalam drama bahasa menjadi unsur nyata. Dalam drama bahasa menjadi unsur utama, namun ada unsur lain yang turut berperan di dalamnya.

Menurut Azhar (2015) drama adalah suatu karya sastra yang ditulis dalam bentuk dialog dan dengan maksud dipertunjukan oleh aktor. Pementasan naskah drama dapat dikenal dengan istilah teater. drama juga dapat dikatakan sebagai cerita yang diperagakan di panggung dan berdasarkan sebuah naskah.

Dari ketiga definisi diatas dapat disimpulkan bahwa drama adalah suatu karya sastra yang ditulis dalam bentuk dialog dan dengan maksud dipertunjukan oleh aktor. Pementasan naskah drama dapat dikenal dengan istilah teater. Drama juga dikatakan sebagai sebagai cerita yang diperagakan dipanggung dan berdasarkan sebuah naskah.

\section{Jenis-Jenis Drama}

Drama juga mempunyai berbagai macam jenis. Karena drama bisa ditampilkan dibalik layar maupun di depan layar. Berikut pembagian jenis drama antara lain:

1) Drama panggung: drama yang dimainkan oleh para aktor dipanggung.
2) Drama Radio: drama radio tidak bisa dilihat dan diraba, tetapi hanya bisa didengarkan oleh penikmat.

3) Drama Film: drama film menggunakan layar lebar dan biasanya dipertunjukan di bioskop.

4) Drama Wayang: drama yang diiringi pegelaran wayang.

5) Drama boneka: para tokoh drama digambarkan dengan boneka yang dimainkan oleh beberapa orang (Bob Susanto, 2015: 56-57).

\section{Metode Drama}

Metode bermain peran (drama) adalah berperan atau memainkan peranan dalam dramatisasi masalah sosial atau psikologis. Adapun tujuan dalam bermain peran yaitu dapat memerankan tokoh tertentu dengan ucapan yang tepat untuk meningkatkan kemampuan berbicaranya sesuai dengan kaidah bahasa Indonesia yang baik dan benar. Seseorang menirukan gaya tokoh yang diidentifikasikan dengan ucapan yang mirip atau sama.

Alat yang diperlukan dalam bermain peran atau drama adalah lembar folio kosong dan kegiatan dilakukan secara perorangan, cara menerapkannya yaitu (1) guru memberikan penjelasan singkat tentang kegiatan hari itu, (2) siswa membagi diri ke dalam kelompok, (3) siswa mengidentifikasi tokoh yang akan diperankan, (4) siswa memerankan tokoh di depan kelompok lain, (5) kelompok lain memberikan komentar tentang peran dari 
anggota kelompok lain, (6) guru mereflesikan hasil pembelajaran itu. Drama yang lebih dibawa pada saat kegiatan drama berlangsung yaitu cerita dongeng, dan cerita dongeng itu pun sangat bermacam-macam (Widiasri, 2011: 56).

Menurut Purnomo (2011) metode drama adalah cara menyajikan bahan pelajaran dengan mempertunjukan atau mempertontonkan atau mendemonstrasikan cara tingkah laku pada kehidupan manusia baik secara resmi dan tidak resmi. Proses interaksi antara siswa dengan guru dalam kegiatan pembelajaran dengan metode drama akan lebih aktif, komunikasi berjalan dua arah dari guru ke siswa dan dari siswa ke guru. Siswa tidak hanya menerima penjelasan materi secara teoritis tetapi juga ikut mengamati dan menganalisa masalah yang yang merupakan ilustrasi dari materi yang akan disampaikan.

Dengan demikian siswa terlibat langsung dalam pembentukan sebuah himpunan sehingga secara nyata ada keterlibatan emosional dan pengamatan indera ke dalam masalah yang dihadapi tersebut. Cara ini akan memunculkan berbagai analisa sesuai tingkat kemampuan dan pemahaman siswa terhadap masalah sehingga tugas guru adalah mengarahakan hasil analisa masingmasing siswa ke dalam simpulan yang sesuai dengan definisi himpunan yang tepat.

Secara umum metode pembelajaran bermain peran dapat digunakan apabila:

1) Pelajaran dimaksudkan untuk melatih dan menanamkan pengertian dan perasaan seseorang.

2) Pelajaran dimaksudkan untuk menumbuhkan rasa kesetiakawanan sosial dan rasa tanggung jawab dalam memikul amanah yang telah dipercayakan

3) Jika mengharapkan partisipasi kolektif dalam mengambil suatu keputusan

4) Apabila dimaksudkan untuk mendapatkan keterampilan tertentu sehingga diharapkan siswa mendapatkan bekal pengalaman yang berharga, setelah mereka terjun dalam masyarakat kelak

5) Dapat menghilangkan malu, dimana bagi siswa yang tadinya mempunyai sifat maludan takut dalam berhadapan dengan sesamanya dan masyarakat dapat berangsur-angsurhilang, menjadi terbiasa dan terbuka untuk menyesuaikan diri dengan lingkungannya.

6) Untuk mengembangkan bakat dan potensi yang dimiliki oleh siswa sehingga amat berguna bagi kehidupan dan masa depannya kelak, terutama yang berbakat bermain drama, lakon film dan sebagainya.

7) Untuk meningkatkan penalaran peserta didik secara lebih kritis dan detail dalam pemecahan masalah.

8) Untuk meningkatkan pemahaman konsep dari materi yang diajarkan

Menurut metode drama adalah sebuah teknik pemecahan masalah yang terjadi dalam konteks hubungan

Menurut Herry (2013) metode drama adalah sebuah teknik pemecahan masalah 
yang terjadi dalam konteks kehidupan dengan cara mendramakan masalahmasalah tersebut melalui sebuah drama. Metode drama memiliki tujuan dan manfaat bagi siswa. Tujuan metode drama bagi siswa adalah (1) siswa berani mengungkapkan pendapat secara lisan, (2) memupuk kerja sama diantara para siswa, (3) siswa menunjukkan sikap berani dalam memerankan tokoh yang diperankan, (4) siswa menjiwai tokoh yang diperankan, (5) siswa memberikan tanggapan terhadap jalnnya pelaksanaan metode drama yang telah dilakukan, (6) melatih cara berinteraksi dengan orang lain.

Manfaat metode drama bagi siswa adalah (1) siswa tidak hanya mengerti persoalan-persoalan psikologis, tetapi mereka juga ikut merasakan perasaan dan pikiran orang lain bila berhubungan dengan sesama manusia, (2) siswa dapat menempatkan diri pada tempat orang lain dan memperdalam pengertian mereka tentang orang lain.

Dari ketiga definisi diatas dapat disimpulkan bahwa metode drama adalah berperan atau memainkan peranan dalam dramatisasi masalah sosial atau psikologis. Bermain peran adalah salah satu bentuk permainan pendidikan yang digunakan untuk menjelaskan perasaan, sikap, tingkah laku dan niali dengan tujuan untuk menghayati perasaan sudut pandangan dan cara berfikir.

Melalui metode drama siswa diajak untuk belajar memecahkan masalah pribadi, dengan bantuan kelompok sosial yang anggotanya teman-temannya sendiri. Dengan kata lain metode ini berupaya membantu individu melalui proses kelompok sosial. Melalui bermain peran, para siswa mencoba mengeksploitasi masalah-masalah hubungan antar manusia dengan cara memperagakannya hasilnya didiskusikan dalam kelas.

\section{Landasan Teori}

Menurut Fahrurrzi dan Wicaksono (2016:15) Bahasa Indonesia baku adalah bentuk bahasa yang telah dikodifikasi atau ditetapkan, diterima dan difungsikan sebagai model oleh masyarakat secara luas. ragam bahasa Indonesia baku juga dari suatu masyarakat bahasa yang disahkan sebagai norma keharusan bagi pergaulan sosial atas dasar kepentingan dari pihakpihak dominan didalam masyarakat itu. Kodifikasi diartikan sebagai hal yang memeberlakukan suatu kode atau aturan kebahasaan untuk dijadikan norma didalam berbahasa. Masalah kodifikasi berkait dengan masalah ketentuan atau ketetapan norma kebahasaan norma-norma kebahasaan itu berupa pedoman tata kalimat, kata, kamus, lafal, dan istilah.

Menurut Hidayah (2016:24) bahasa Indonesia baku adalah salah satu ragam bahasa Indonesia yang bentuk bahasanya telah dikodifikasi, diterima dan di fungsikan atau dipakai sebagai model oleh masyarakat Indonesia secara luas, tetapi dipakai masyarakat secara khusus. 
Menurut Widada dan Prayogi (2010:270) bahasa Indonesia baku adalah yang digunakan oleh masyarakat yang paling luas pengaruhnya dan paling besar wibawanya. Salah satu wujud bahasa baku Indonesia adalah kamus besar bahasa Indonesia yang disusun secara sistematis oleh pusat bahasa.

Dari ketiga definisi bahasa Indonesia baku diatas dapat disimpulkan bahwa bahasa Indonesia baku adalah ragam bahasa yang cara pengucapan dan penulisannya sesuai dengan kaidah-kaidah standar. kaidah standar dapat berupa pedoman ejaan yang disempurnakan (EYD), tata bahasa baku, dan kamus umum.

\section{PEMBAHASAN}

Kemampuan Berbahasa Indonesia Sebelum Menggunakan Metode Drama
Perimbangan
Nilai,
Predikat

Kemampuan Berbahasa Indonesia Sebelum Melakukan Metode Drama Pada Siswa Kelas VIIC SMP Dharma Praja

Tabel 1 Kemampuan Berbahasa Indonesia Sebelum Menggunakan Metode Drama

\begin{tabular}{|l|c|c|c|}
\hline No & Nilai & Predikat & Jumlah Siswa \\
\hline 1. & 100 & Sangat Baik & 14 \\
\hline 2. & 72 & Cukup & 12 \\
\hline 3. & 66 & Cukup & 4 \\
\hline
\end{tabular}

\section{Kemampuan Berbahasa Indonesia}

\section{Setelah Menggunakan Metode Drama}

Perimbangan Nilai, Predikat

Kemampuan Berbahasa Indonesia Setelah
Melakukan Metode Drama Pada Siswa Kelas VIIC SMP Dharma Praja

Tabel 2 Kemampuan Berbahasa Indonesia Setelah Menggunakan Metode Drama

\begin{tabular}{|l|c|c|c|}
\hline No & Nilai & Predikat & Jumlah Siswa \\
\hline 1. & 100 & Sangat Baik & 33 \\
\hline 2. & 66 & Cukup & 2 \\
\hline 3. & 38 & Kurang & 1 \\
\hline
\end{tabular}

Faktor-Faktor Yang Menyebabkan Kesalahan Dalam Berbahasa Indonesia

Faktor-faktor yang menyebabkan kesalahan dalam berbahasa Indonesia pada responden tergolong banyak. Faktor-faktor kesalahan tersebut membuat para responden susah untuk berbahasa Indonesia yang relevan. Adapun faktor-faktor yang menyebabkan kesalahan dalam berbahasa Indonesia pada responden sebagai berikut.

1) Faktor penyebab kesalahan pertama adalah responden lebih cenderung menggunakan bahasa campuran yaitu campuran bahasa Bali dan bahasa Indonesia dalam kesehariannya daripada menggunakan bahasa Indonesia yang utuh. Hal tersebut disebabkan karena lingkungan rumah dan pergaulan para responden masing-masing. Hal tersebut membuat para responden tidak memahami berberbahasa Indonesia dengan baik.

2) Faktor penyebab kesalahan kedua adalah sebagian besar responden tidak terlalu menyukai pelajaran bahasa Indonesia di sekolah, disebabkan oleh proses belajar mengajarnya yang masih monoton. Hal tersebut disebakan oleh pada saat proses 
belajar mengajar guru bahasa Indonesia hanya menyuruh responden lebih sering untuk mencatat dan guru jarang menggunakan metode yang bervariasi untuk menarik minat belajar responden khususnya pelajaran bahasa Indonesia.

3) Faktor penyebab kesalahan ketiga adalah kurangnya keberanian responden dalam berbicara di depan umum pada saat pada saat guru menunjuknya ke depan kelas, dalam hal tersebut dikarenakan guru kurang melibatkan responden dalam proses belajar mengajar dalam pelajaran bahasa Indonesia guru harus lebih sering melibatkan responden dalam berbicara di depan kelas agar mental responden lebih berani berbicara di depan umum, hal tersebut juga bisa membuat responden lebih cepat memahami berbahasa Indonesia dengan baik.

4. Faktor penyebab kesalahan keempat adalah responden belum memahami pemakaian berbahasa Indonesia yang relevan, hal itu disebabkan oleh sedikitnya informasi tentang berbahasa Indonesia yang relevan didapatkan responden dari guru, sehingga responden hanya menggunakan bahasa Indonesia pergaulan. Dan responden hanya memahami bahasa Indonesia pergaulan saja.

Keempat faktor penyebab kesalahan berbahasa Indonesia yang relevan tersebut harus bisa ditanggulangi oleh metode yang bisa membuat responden tertarik untuk memahami berbahasa Indonesia yang relevan. Salah satunya adalah metode drama yang bertema pendidikan karena dari metode drama bertema pendidikan responden menjadi lebih tertarik untuk memahami dan mengetahui bahasa Indonesia yang relevan.

\section{SIMPULAN}

Hasil sebelum menggunakan metode drama dalam kemampuan berbahasa Indonesia siswa kelas VIIC pada penilaian awal di katakan $86 \%$ responden belum bisa mencapai nilai KKM yaitu 76 , terutama dalam bagian diksi dan tata bahasa. Nilai responden pada penilaian awal yaitu 100, $72,66,38$ responden yang mendapat nilai 100 yaitu berjumlah 14 orang yang termasuk predikat sangat baik, responden yang mendapat nilai 72 yaitu berjumlah 12 orang yang termasuk predikat cukup, siswa yang mendapat nilai 66 yaitu berjumlah 4 orang, dan siswa yang mendapat nilai 38 yaitu berjumlah 6 orang

Responden yang melakukan kesalahan di bagian diksi pada saat awal penilaian yaitu berjumlah 18 orang, sedangkan jumlah responden yang melakukan kesalahan bagian tata bahasa sebanyak 9 orang. Hal tersebut menunjukkan bahwa masih kurangnya pengetahuan siswa pada berbahasa Indonesia terutama dalam bidang diksi dan tata bahasa, agar siswa kelas VIIC bisa meningkatkan berbahasa Indonesia terutama dalam bidang diksi dan tata bahasa peneliti menerapkan metode drama bertema 
pendidikan.

Hasil berbahasa Indonesia responden setelah menerapkan metode drama menjadi lebih baik dari sebelumnya. Hal tersebut terbukti pada penilaian akhir sebesar 93\% responden mengalami peningkatan sekaligus melebihi nilai KKM yaitu 76, jumlah responden yang mendapat nilai 100 yaitu 33 siswa dengan predikat sangat baik, sedangkan jumlah responden yang mendapat nilai 66 yaitu 2 orang dengan predikat cukup, dan jumlah responden yang mendapat nilai 38 yaitu 1 orang dengan predikat kurang.

Responden yang melakukan kesalahan di bagian diksi pada saat penilaian akhir yaitu berjumlah 1 orang, sedangkan responden yang melakukan kesalahan di bagian tata bahasa yaitu berjumlah 2 orang. Berdasarkan hasil peningkatan responden pada penilaian akhir dapatlah disimpulkan bahwa metode drama dengan cerita formal dapat meningkatkan kemampuan berbahasa Indonesia pada siswa kelas VIIC SMP Dharma Praja.

\section{UCAPAN TERIMA KASIH}

Penulis mengucapkan terima kasih kepada mitra bestari atas kritikan dan masukan yang membangun untuk perbaikan artikel ini.

\section{DAFTAR PUSTAKA}

Arnawa Nengah. 2008. Wawasan Linguistik Dan Pengajaran Bahasa. Denpasar: Putri Praptama Offset Printing.

A Alek., H. H.P Ahcmad. 2010. Bahasa Indonesia untuk Perguruan Tinggi.
Jakarta: Kencana Prenada Media Group.

Aliseptiansyah, 2014. Bahasa Indonesia Yang Baik dan Benar. Diunduh dari www.wordpress.com (waktu pengunduhan 16 Juni 2016) Pukul 10.58 Wita

Ariana I Kadek. 2013. Korelasi Intensitas Penggunaan Bahasa Bali Terhadap Kemampuan Berbicara Siswa Kelas X SMK Negeri 1 Denpasar Tahun Pelajaran 2012/2013. (Skripsi tidak diterbitkan)

Astutik Anik. 2014. Upaya Meningkatkan Berbicara Bahasa Indonesia Melalui Teknik Bercerita Berpasangan Pada Siswa Kelas IV MI YAPPI Nologaten Ngawen Gunungkidul Tahun Ajaran 2013/2014 (Tesis tidak diterbitkan)

Azhar Azmi. 2015. Pengertian Drama, JenisJenis Drama, Dan Unsur-Unsur Drama. Diunduh dari gopengertian.blogspot.com (waktu pengunduhan 12 januari 2017) pukul 11.00 wita

Badricenter.org, 2017. Fungsi Bahasa Indonesia. Diunduh dari https:// badriyadi.wordpress.com (waktu pengunduhan 08 Janurai 2017) pukul 17.30 Wita

Edi Suardi Yuda I Made. Pengajaran Langsung (Direct Instruction) Sebagai Upaya Meningkatkan Kemampuan Berbicara Bahasa Bali Pada Siswa Kelas X AP4 SMK Pariwisata Kertayasa, Singakerta, Ubud Tahun Pelajaran 2013/2014. (Skripsi tidak diterbitkan)

Fauzi, Achmad. 2011. Pintar Bahasa Indonesia, Pengetahuan Sastra dan Tata Bahasa. Mahir Sindo Utama.

Fahrurrozi dan Wicaksono. 2016. Sekilas Tentang Bahasa Indonesia. Yogyakarta: Garudhawaca

Fildzahvzka. 2015. Pengertian Diksi. Diunduh dari https://fildzahvka.blogspot.com (waktu pengunduhan 13 januari 2017) pukul 10.51 wita

Herrystw. 2013. Teknik drama. Diunduh dari https://herrystw.wordperss.com (waktu pengunduhan 14 januari 2017) pukul 12.23

Hidayah Nurul. 2016. Pembelajaran Bahasa Indonesia. Yogyakarta: Garudhawaca

Juniardianta I Nyoman. 2013. Penggunaan Metode Bercerita Untuk Meningkatkan Kemampuan Berbicara Kelas X-1 SMA Negeri 8 Denpasar Tahun Pelajaran 2012/2013. (Skripsi tidak diterbitkan)

M.S Mahsun. 2005. Metode penelitian bahasa : tahapan strategi, metode dan Tekniknya. Jakarta : PT Raja Grafindo 
Persada.

Martaulina. 2015 Bahasa Indonesia Terapan. Yogyakarta: DEEPUBLISH

Markijar. 2016. Tata Bahasa Indonesia (lengkap pengertian, sifat dan macamnya). Diunduh dari www.markijar.com(waktu pengunduhan 16 januari 2017) pada pukul 11.37 wita

Nurkancana Dan Sunarta. 1992. Evaluasi Hasil Belajar. Surabaya: Usaha Nasional

Pamungkas, Sri. 2012. Bahasa Indonesia Dalam Berbagai Perspektif. Andi Yogyakarta.

Pilamirifka. 2015. Konsep Bahasa Dan Fungsi Bahasa. Diunduh dari rifkapilami.blogspot.com (waktu pengunduhan 8 januari 2017) pukul 12.27 Wita

Purnomo Gilang Bayu. 2011. Metode Drama Dan Bermain Peran. Diunduh dari purnama-bgp.blogspot.com (waktu pengunduhan 14 januari 2017) pukul 11.36 wita

Pudentia MPSS. 2015. Metodologi Kajian Tradisi Lisan. Jakarta: Asosiasi Tradisi Lisan

Suwito dkk. 2015. Cerdas Bahasa Indonesia. Denpasar: Catur wangsa Mandiri

Susanto Bob. 2015. Jenis-Jenis Drama Dan Penjelasan Lengkapnya. Diunduh dari www.seputarpengetahuan.com (waktu pengunduhan 07 Mei 2016) Pukul 10.26 Wita
Sugono Dendy. 2009. Mahir Berbahasa Indonesia. Jakarta: PT Gramedia Pustaka Utama.

Suratmisiti. 2014. Pengertian Drama Jenis-Jenis Drama Dan Manfaat Mempelajari Drama. Diunduh dari suratmisistisuratmi.blogspot.com (waktu pengunduhan 12 januari 2017) pukul 11.15 wita

Widiasri Dewa Ayu. 2011. Metode Pengajaran Bahasa Dan Sastra Indonesia. IKIP PGRI BALI

Widada dan Prayogi. 2010. Kamus Saku Bahasa Indonesia. Yogyakarta: Tim Bentang Pustaka

Yudi. 2015. Pengertian prolog, Epilog, Dialog Dan Monolog Dalam Drama. Diunduh dari www.pelajaransekolah.net (waktu pengunduhan 17 januari 2017) pukul 10.04 wita

Zabadi Fairul dan Sutejo dkk. 2014. Bahasa Indonesia Wahana Pengetahuan Balitbang: Pusat Kurikulum Dan Perbukuan Kemdikbud. 